\title{
(De)Forestation in Vietnam: A Political Ecology Perspective
}

\author{
Thi Thuy Hang Nguyen ${ }^{1, *}$ and Rajeshwar Singh ${ }^{2}$ \\ ${ }^{1}$ University of Social Sciences and Humanities, Vietnam National University, 336 Nguyen Trai \\ Street, Hanoi, Vietnam \\ ${ }^{2}$ Centre for the Study of Law and Governance, Jawaharlal Nehru University, New Delhi, India
}

\begin{abstract}
In 1995, the forest coverage area in Vietnam was $27.2 \%$, but by 2019 , it reached to $41.89 \%$. The Government claims that the fast-growing forest coverage is highly contributing to GDP. However, recent studies reveal that the economic growth rate of ethnic minorities in the forest area is very slow. Some studies have been conducted on the Government's efforts to reforest over the years. However, very few studies have carried on (de)forestation in Vietnam from the perspective of political ecology. The present article co-relates (de)forestation in Vietnam with ecosystems, socio-economic status, and politics. The paper presents the study in four broad sections. The first segment explores the current situation of forests in Vietnam. In the second part, the paper discusses the impacts of (de)forestation on the ecosystem. Thirdly, the article analyses impact of (de)forestation on the socio-economic development of Vietnamese citizens. Finally, the paper discusses the conclusions approaching from the perspective of the Government and citizens, before turning to the end, it proposes some policy-recommendations for public and private stakeholders to promote and protect the forestry sector in Vietnam.
\end{abstract}

\section{Introduction}

The term "political ecology" has been widely used in the academic world; however, it is a new concept in Vietnam. Frank Thone coined this terminology first time in his article published in 1935 [1]. Then the word was popularly known, but it received a systematic definition very later. In 1972, Eric R. Wolf, in an article titled "Ownership and Political Ecology," discussed how local rules of ownership and inheritance "mediate between the pressures emanating from the larger society and the exigencies of the local ecosystem" [2]. However, Wolf did not develop the concept further than the shallow discussion. The broader framework of 'Political Ecology' emerged only in the 1980s as the result of the development of geography and cultural ecology, especially in work, "The Political Economy of Soil Erosion in Developing Countries," of Piers Blaikie [3], an expert in rural development and resource governance.

\footnotetext{
* Corresponding authors: hangkhct@,vnu.edu.vn
} 
After a long time, Michael Minch (2011) defined this term holistically as, "political ecology is the study of the intersection and relationship between the political, broadly understood, and environmental and ecological phenomena. Political, economic, social, and cultural forces affect, and are affected by, ecological and environmental trends" [4] According to him, the political economy has a broad scope and is an interdisciplinary concept, and there are many definitions and understandings on this subject.

Blaikie and Brookfield stressed the political economy [5]. At the same time, Bryant Raymond, in the article entitled "Power, knowledge and political ecology in the third world: a review" focused on political ecology in the third world [6]. Many other social scientists, such as Peet and Watts, pointed to the more formal political institutions [7], [8]. James B. Greenberg also tried to find out the definition of political ecology. He focused on the political ecology of economic development, and the history of its impacts [9]. D. Rocheleau wrote about "gender and a feminist political ecology" [10], Mark Q. Sutton, and E.N. Anderson focused on "Cultural Ecology" in the field of political ecology. [11]. Similarly, Peter A. Walker has tried to trace the importance of the ecological sciences in the political ecology raising the question that "Political ecology: where is the ecology?" [12]. He pointed out the transition through the 1970s and 1980s, in which ecology was considered a core part of the discipline, to a perspective that emphasized on the 'politics' in political ecology. Therefore, political ecology has been researched in a variety of academic disciplines, including geography, forestry, economics, anthropology, environmental history, sociology, development studies, and political science.

In the field of forestation and deforestation in Vietnam, some scholars have discussed spatial associations between poor populations and environmental problems, including deforestation. For example, the paper entitled "Where is the poverty-environment nexus? Evidence from Cambodia, Lao PDR, and Vietnam" showed that the nexus was quite different in each country [13]. Some scholars have focused on the relation between 'illegal' logging and land tenure, poverty, and forest using-rights in Vietnam [14]. Some researchers have found the underlying causes of deforestation in the Mekong Region [15]; some researchers have studied the relationship between land tenure for small landholder agriculture and deforestation in Vietnam [16].

On the other hand, some studies have investigated drivers of deforestation and forest degradation at the national level in Vietnam [17]; some have focused on assessing the ecological vulnerability of forest landscape to agricultural frontier expansion in the Central Highlands of Vietnam [18]. However, almost no study has been focused on (de)forestation in Vietnam from the view of a political ecology perspective. Therefore, this paper analyses the socio-political and environmental impacts of forestation and deforestation in Vietnam from a perspective of political ecology.

The further discussion on the political ecology perspective based on three fundamental assumptions of political ecology, which are developed by Raymond L. Bryant and Sinead Bailey as: First, changes in the environment do not affect society in a homogenous way: political, social, and economic accounts for the uneven distribution of costs and benefits. Second, any change in environmental conditions must affect the political and economic status quo. Third, the unequal distribution of costs and benefits and the reinforcing or reducing of pre-existing inequalities have political implications in terms of the altered power relationships that then result [19].

In this way, the paper not only focuses on analyzing policy-making and organizational complexities surrounding forestation and environmental development, but it also looks into how unequal relations in and among societies affect the natural environment. The paper also tries to decode the decisions that communities make about forestation and deforestation in the context of their political environment, economic pressure, and societal regulation. 
There are many measures to define a forest, including forest cover, forest area, and tree cover. FAO definition uses "forest area" and defines forests as "land spanning more than 0.5 hectares with trees higher than 5 meters and a canopy cover of more than 10 percent, or trees able to reach these thresholds in situ." This definition of forests does not include land that is predominantly under agricultural or urban land use [20]. On the other hand, the Global Forest Watch (GFW) uses "tree cover" and defines it as "the biophysical presence of trees and may take the form of natural forests or plantation existing over a range of canopy densities" [21] The Government of Vietnam uses "forest coverage" instead and defines as forest coverage is the percentage of existing forest area compared to the natural area of the whole country, a territory or a locality at a given time (General Statistics Office (GSO), "Indicator: Land coverage (percentage), 2019). The differences in definitions are useful in understanding the data and see the ecosystem services, which count the natural forest different from the plantations. It also helps to understand how forests can contribute to reducing the impacts of climate change.

\section{Materials and Methods}

The paper uses the literature review as a methodology. The main sources of data for this paper are the data published by the General Statistics Office of Vietnam, the official web portal of the Government of Viet Nam, and the official web sites of the National Assembly of Viet Nam, Ministry of Agriculture and Rural Development, Vietnam Administration of Forestry. This study also explores some newspapers, which cover news related to forestation and deforestation in Viet Nam.

The paper adopts historical, descriptive, and analytical research methods. As this paper approaches a political ecology perspective, it investigates the spatial-ecological influences on politics and power, a scope reminiscent of environmental politics.

\section{Results}

\subsection{Forest in Vietnam}

Vietnam is popularly known for its abundant forest resources in the world. In recent years, however, the forest resources are depleting because of its gradual over and illegal exploitation. The programs and policies of the Government show that the Government is mobilizing citizens to attend the forestation movement, so the country could overcome this situation.

Forestation, also known as the forestation movement, is a system of planting trees, a technical solution, applied for the purpose of growing artificial forests, including many stages, such as survey preparation, creating seedlings, planting and tending, nurturing, and protecting forests to achieve productivity, quality, and efficiency. Forestation applies to non-forest or forestland, including coastal wetlands, estuaries, and swamps.

In the case of Viet Nam, the Government regulates the identification and classification of forests and also carries out resources management activities for them. According to the circular No.34/2009/TT-BNNPTNT, the Ministry of Agriculture and Rural Development has set the criteria for determining and classifying forest. The forests have been divided into six categories, as follows: 1. Based on the purpose: protection forest, special-use forest, and production forest; 2. Based on the origin: natural forest, planted forest; 3. Based on the site conditions: forest in mountain land, forest in the rocky mountain, flooded forest, forest on sandy soil; 4. Based on the species: wood forest, bamboo forest, coconut forest, mixed wood, and bamboo; 5. Based on the reserve: for the woodland forest and bamboo 
forest; 6. Land without forests: land with plantation forest, vacant land that has regenerated wood, vacant land without regenerated timber, rocky mountains without trees. The knowledge of these classifications of forests is essential to understand the (de)forestation in Vietnam.

Over the past decade, Vietnam has reported considerable efforts in forest management and forest protection. According to the data published by the General Statistics Office of Viet Nam, the total forest area is 14.609.2 thousand hectares which comprises natural forests 10.292.4 thousand hectares and plantation 4.316.8 thousand hectares (see Table 1). The forest cover rate reached $41.8 \%$ by the end of 2019. According to Voices for Mekong Forest "Vietnam is the only country in the Mekong region to have reported a continuous increase in its forest cover over the last three decades" [22].

By 2030, the Vietnamese Government aims to stabilize the natural forest area to at least equal to the area achieved in 2020 and increase the national forest coverage to $45 \%$ (Decision No.419/QĐ-TTg of the Prime Minister dated 5 April 2017, approving the National Action Programme on the Reduction of Greenhouse Gas Emissions through the Reduction of Deforestation and Forest Degradation, Sustainable Management of Forest Resources, and Conservation and Enhancement of Forest Carbon Stocks (REDD+) By 2030).

Table 1. The forest status in Vietnam (Unit: Thousand Hectares). Sources: General Statistics Office, Statistical Yearbooks 2005-2019.

\begin{tabular}{|c|c|c|c|}
\hline Year & Natural forest & Planted forest & $\begin{array}{c}\text { Total area of forest } \\
\text { land }\end{array}$ \\
\hline 2005 & 9.529 .40 & 2.889 .10 & 12.418 .50 \\
\hline 2006 & 10.177 .70 & 2.486 .20 & 12.663 .90 \\
\hline 2007 & 10.188 .20 & 2.551 .10 & 12.739 .30 \\
\hline 2008 & 10.348 .60 & 2.770 .10 & 13.118 .70 \\
\hline 2009 & 10.339 .30 & 2.919 .50 & 13.258 .80 \\
\hline 2010 & 10.304 .80 & 3.083 .30 & 13.388 .10 \\
\hline 2011 & 10.285 .40 & 3.229 .70 & 13.515 .10 \\
\hline 2012 & 10.423 .80 & 3.438 .20 & 13.862 \\
\hline 2013 & 10.398 .10 & 3.556 .30 & 13.954 .40 \\
\hline 2014 & 10.100 .20 & 3.693 .30 & 13.796 .50 \\
\hline 2015 & 10.175 .50 & 3.886 .30 & 14.061 .90 \\
\hline 2016 & 10.242 .10 & 4.135 .60 & 14.377 .70 \\
\hline 2017 & 10.236 .41 & 4.178 .96 & 14.415 .38 \\
\hline 2018 & 10.255 .52 & 4.235 .77 & 14.491 .29 \\
\hline 2019 & 10.292 .43 & 4.316 .78 & 14.609 .22 \\
\hline
\end{tabular}

The table shows that the total area of forest land in Vietnam has gradually been increasing. According to the table, the natural forest has been decreasing slightly in some years. However, the planted forest has been gradually increasing. According to a report by Ministry of Agriculture and Rural Development: "Forestation has been actively implemented, an average of 225.000 ha of concentrated forest planted annually, of which over $90 \%$ is production forest, plantation productivity continues to be improved" (Xuan Tuyen, "Using enterprises as the driving force for forestry economic development", Online 
Newspaper of Government, 20/7/2017). The government's interest in growing forests shows that "any change in environmental conditions must affect the political and economic status quo" [19]. The Government's forest policy plays an essential role in forestation in Vietnam.

There are two forest-related laws in Vietnam, which are playing a central role in the promotion and protection of forests. They are 'The Forest Protection and Development Act' originally passed in 1991 and revised in 2004 and 2016, and the 'Forest Law 2017' that took effect from January 1. 2019. Since 1991. the Government has started to reform the forestry sector. According to the reform policy, the Government shifted the ownership of state-controlled forests to the community management committee. The Forest Protection and Development Act amended in 2004 and 2016 for the aspects of sustainable development of forests. "Changes in forest ownership and utilization have not only been reflected in changes in the structure of forest and utilization but have also resulted in the establishment of a nationwide forest owner system" [23].

Politics, Government's policies, and laws are comprehensively influencing for forestation in Viet Nam. First, the Government has been encouraging community participation in forestation. Forests are handed over to users (including organizations and individuals) and also encouraging participation of the private sector. The government has also implemented the policy of decentralizing management to the grassroots level. According to the Ministry of Agriculture and Rural Development, State-managed forest land fell from $80.1 \%$ in 2000 to $45.2 \%$ in 2015 , and the non-state sector was correspondingly growing from $19.9 \%$ to $54.8 \%$. Households and individuals were allocated 3,146 million ha (PV, "Sustainable forestry development for 2016-2020", The World and Vietnam Report, 20/07/2017). "The State budget mainly invests in special-use forest and protection forest and accounts for only about 25 percent of the total social investment in forest protection and development. $75 \%$ of the invested capital is mobilized from sources other than the state budget" (Dr. Ha Cong Tuan, Vice Minister of Ministry of Agriculture and Rural Development, "Looking back on forestry 2011-2015, orientation for sustainable development until 2020", Vietnamese Agriculture Newspaper 26/11/2015).

Second, the Government of Viet Nam has very effective policies on forest protection and development. The forest sector was one of the first natural resources sectors in Vietnam to implement these policies. Some examples of policies and mechanisms are as follows: Decree No.05/2010/ND-CP for the establishment of Forest Protection and Development, Decree No.99/2010/ND-CP for the payment of forest environment-related services, Decree No.75/2015/ND-CP on mechanism and policies for forest protection and development, Policy for fast and sustainable poverty reduction and support for ethnic minorities from 2015-2020.

Besides, the Government also has a Decision No.1288/QD-TTg on Sustainable Forest Management and Forest Certification Program 2016-2020. These policies have helped to improve the regulation of forests. "Policies now are more comprehensive, State management by law has progressed, and social awareness of forest sector has increased" (Dr. Ha Cong Tuan, "Looking back on forestry 2011-2015, orientation for sustainable development until 2020", Vietnamese Agriculture Newspaper 26/11/2015).

Third, the Government of Viet Nam has policies to support international organizations to invest in many forest-related programs and projects. Such as The 327 Program (19931998), 5 Million Hectares Reforestation Program (1998-2010), World Bank's Forest sector development project (2004-2011), and The Project of Modernizing the Forestry Sector and Strengthening the Resilience of Coastal Areas (ongoing since 2017). Besides these, the Government also has some projects funded by different development partners-Japan, the 
Netherlands, Finland, and Germany. These projects work for the improvement of forest cover and quality as well as increase the economic value of timber products that meet domestic demand and export to the world market [24].

The above-discussed pieces of evidence show that politics, the Government's policies, and laws are strongly influencing forestation, meaning on the earth's surface, and the ecology. On the other hand, however, spatial-ecological influences on politics and economics also hugely contribute to the stable political system because it connects to the distribution of cost and benefits. The report states that "[ $[$ ] $]$ he quantity and quality of forests have improved in the last few years, and turnover in the forestry sector has resulted in economic growth. Communities have benefited from the increase in financial support and job creation from this growth." [25]

\subsection{Impacts of (de)forestation on ecosystem}

Forest plays a significant role in keeping a valuable ecological resource to mitigate climate change. The National Strategy on Climate Change issued by Prime Minister of Viet Nam in Decision No. 2139/QĐ-TTg on 05 December 2011. states the statistics of climate change in the county as:

"Viet Nam is considered as one of the countries most affected by climate change, its Mekong Delta is one of the world's three most vulnerable deltas (together with the Nile Delta in Egypt and the Ganges Delta in Bangladesh) to the sea level rise. According to climate change scenarios, in late $21^{\text {st }}$ century, Viet Nam's yearly mean temperature will go up by $2-3^{\circ} \mathrm{C}$, the total yearly and seasonal rainfall increases while the rainfall in dry seasons will decrease, the sea level can rise by $75 \mathrm{~cm}$ to $1 \mathrm{~m}$ compared to the 1980-1999 period. If the sea level rises by $1 \mathrm{~m}$, about $40 \%$ of the Mekong Delta area, $11 \%$ of the Red River Delta and $3 \%$ of coastal provinces will be inundated (over $20 \%$ of Ho Chi Minh City flooded); about $10-12 \%$ of Viet Nam's population is directly impacted, and the country will lose around $10 \%$ of GDP."

"Over the past years, due to climate change, the frequency and intensity of natural disasters have increased, causing great human and property losses, damaging socioeconomic and cultural infrastructure, and imposing negative impacts on the environment. In the last decade (2001-2010), such natural disasters like floods, flash floods, landslides, inundations, droughts, soil, and water salinity, and other calamities have resulted in 9,500 deaths and missings as well as damaged about 1.5\% of annual GDP." (The National strategy on climate change was issued by Prime Minister in Decision 2139/QĐ-TTg on December 05, 2011. p.1)

According to the Climate Risk Index published by Germanwatch in December 2015, Vietnam is also among the ten countries most severely affected by climate change in the past 20 years because of storms, floods, and landslides. The impact of climate change in Vietnam is severe, and it is an existing threat to the goal of poverty reduction, the millennium goal, and sustainable development. "The average temperature in Vietnam is forecast to rise around 1.5 degrees Celsius with most results near the median. For all areas in Vietnam, the temperature rise ranges from a minimum of less than 1 degree $\mathrm{C}$ to a maximum of more than 2 degrees Celsius" [26].

Forests' ecosystems maintain biodiversity, especially tropical forests like in Vietnam, and the conservation of biodiversity is an essential factor in forest development as well as in national sustainable development. Sustainable forest protection and development is also a guarantee for the conservation of biodiversity and natural ecosystems. Therefore, the forestation and the conservation of biodiversity are similar to a reversible process. However, the protection and development of forests always face severe challenges, 
especially in developing countries like Vietnam, where the majority of the population still relies on agricultural cultivation. Forests are not only the basis for socio-economic development but also hold an essential ecological function. Forests participate in the process of climate regulation, ensuring the circulation of oxygen and other essential elements on the planet.

Forests maintain soil stability and fertility, limit floods and droughts, prevent soil erosion, mitigate the devastating effects of natural disasters, conserve saltwater and groundwater resources, and do reduce air and water pollution. Vietnam stretches across the latitudes and high belts, with very diverse topography, more than $2 / 3$ of the territory is hilly, climate changes from the humid tropical South, to the subtropical in the Northern highlands, creating a diversification of the natural ecosystem and the richness of species. These ecosystems include a variety of forests according to site conditions or according to species.

According to Prof. Nguyen Ngoc Lung, a leading expert in Vietnam's forestry sector, when floods, landslides, and droughts occur, besides the causes of climate change and extreme weather, it is clearly due to deforestation. Tropical forests have many layers, some trees are $40-50 \mathrm{~m}$, and below there are vegetation cover and other layers. If the rainfall is not enough, the water only stays on the layers of the leaves, not even falling to the ground. When the rain falls to the ground, there is the first layer of rotten tree (branches, leaves, etc.) that hold the water up to $80-90 \%$ and soak into the ground to form groundwater. Moreover, $10-20 \%$ of surface water is a small amount, less likely to cause pipe floods, flash floods for humans. When there are tropical forests, even though the land is sloping, there is no concern about flash floods or landslides. Therefore, even though the natural forest runs out of wood, it still works to ensure the environment and regulate water, even though the forest is sparse. With other types of forests, it only works to prevent floods and keep the water about 20-50\% compared to natural forests (Nam Khanh, "Flash floods and landslides due to deforestation: Who is responsible?" Tien Phong Newspaper, 16/10/2017).

Deforestation in Vietnam is now becoming a top issue that needs to be addressed thoroughly. The Government data shows that the natural forest area is decreasing day by day. According to the research report published by the Institute of Forest Investigation and Planning, Ministry of Agriculture and Rural Development, in 1945, the total forest area in Vietnam was 14.3 million hectares; the forest coverage rate was 43.8\%. However, in 1976 the forest area decreased to 11.6 million hectares and the forest coverage rate to $33.8 \%$. During the 30 years of war (1945-1975), Vietnam's forests shrank quite quickly. More than 80 million liters of herbicide, 13 million tons of bombs, and 25 million bomb craters, wildfire bombs, and a giant bulldozer team destroyed more than 2 million hectares of tropical forests of all kinds. Furthermore, the research found that "in 20 years (1975-95), the natural forest area of the whole country decreased by 2.8 million hectares. The most severely reduced forest areas were the Central Highlands with the loss of 440,000 hectares, Southeast region 308,000 hectares, the old area of North Area IV 243,000 ha, and the Northern region 242,500 hectares" (PV, "An overview of Vietnam's natural forests since 1945", Vietnamplus, 10/01/2017). 


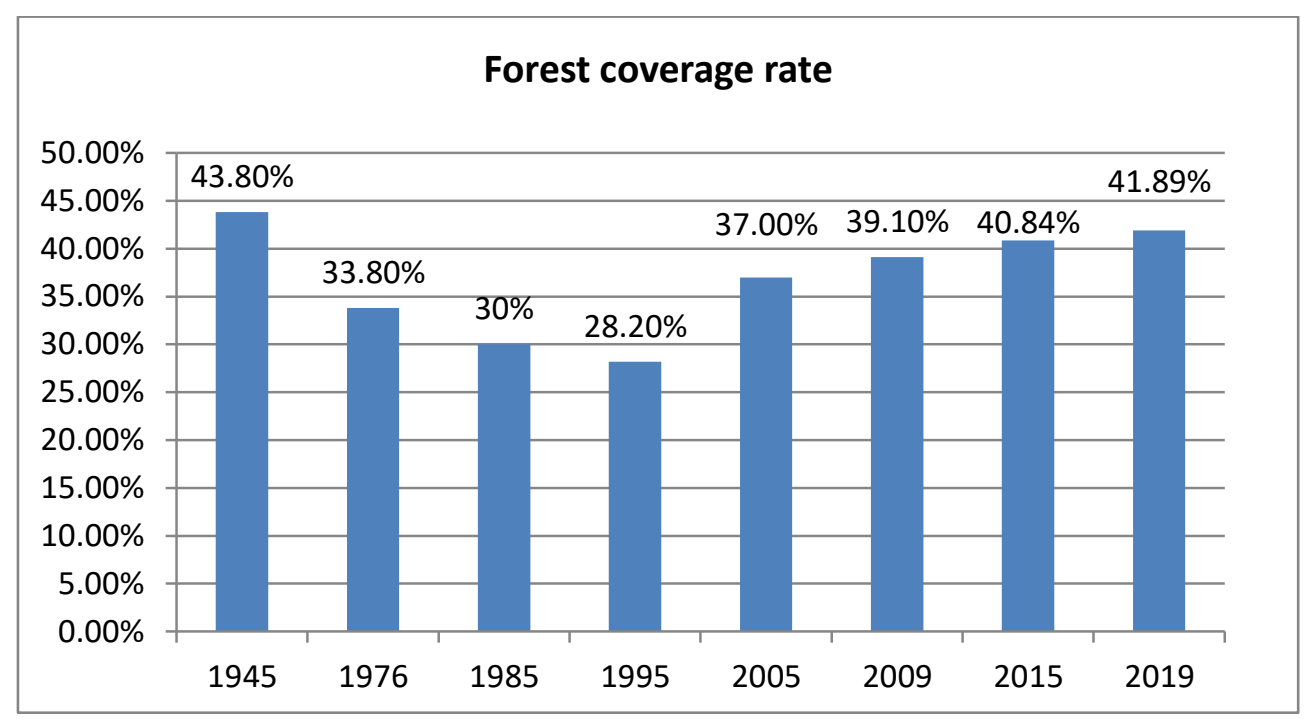

Fig. 1. The Forest coverage rate in Vietnam (unit: \%). Sources: General Statistics Office.

Forest is one of the prerequisites for mitigating environmental problems. The Vietnamese Government always focuses on environmental protection as an essential task. However, in reality, deforestation continues to be an increasingly complex task in the country. In fact, the area of natural forest in Vietnam is rapidly declining at a dizzying rate, especially the forest coverage in the central region. According to the Global Forest Watch report "from 2002 to 2019, Vietnam lost 669kha of humid primary forest, making up 24\% of its total tree cover loss in the same period. Total area of humid primary forest in Vietnam decreased by $9.8 \%$ in this period." (Global Forest Watch, "Tree cover lost in Vietnam", 2019).

There are many reasons for the decrease of natural forests in Vietnam. Some main reasons are as follows:

Firstly, natural forests decreased because of the use of forest and forest-land for the other purpose. According to the data published by the Vietnam Administration of Forestry (MARD), 11 percent of the natural forest area was lost due to illegal deforestation activities just in five years (2012-17). The remaining 89 percent area was approved for the use in other purpose projects (Kim Yen, "Viewpoints of representatives: What solution for deforestation", Electronic Portal of the National Assembly of the Socialist Republic of Vietnam, 27/2/2020). In the last five years, the Government has approved a large area of forest land for the use of other purpose projects. According to the news report published in Tien Phong, "due to the need for land for hydropower, golf courses, and resort construction, the conversion of forest and forestry land uses has been massive in many localities. The synthesis reports from 58 provinces and cities across the country showed that State agencies have approved nearly 38,300 ha forests for the use of other purposes 1.892 projects. That approval includes natural forest nearly 19,000 ha, the planted forest over 15,800 ha, and the land without forest planned for forestry over 3,500 ha" (Tien Phong Newspaper, 16/10/2017).

It shows a series of conversion of forest and forest-land into other using purpose took place in many provinces and cities in Vietnam. For example, the project of New City Vietnam high-end tourist complex, the investment project to raise high-quality beef cattle in Phu Yen, the project of the super cemetery, the use of protective forest land in Ngang mountain area (Bo Ly commune, Tam Dao) in Vinh Phuc. Particularly, the project of the New City Vietnam high-end tourist complex has not had the approval of the Prime 
Minister. However, the locality has allowed the construction and felling of forests in contravention of regulations. The project of developing high-quality beef cattle in forest sub-areas 310, 311 in Song Hinh district, was not included in the approved land-use plan. According to the news report, the massive public opposition against the project of super cemetery drew the attention of the Government. The public demonstration made Deputy Prime Minister, Truong Hoa Binh, to ask Vinh Phuc to check and clarify information as reflected in the press as "Vinh Phuc: Cut protective forests for the cemetery or dig minerals" (Tien Phong Newspaper, 16/10/2017). The above examples reveal that any change in environmental conditions must affect the political and economic status quo.

The conversion also converted forests and forest land into agricultural land in many places throughout the country. Outdated farming practices, shifting cultivation, and dependence on forest resources still exist for survival in Vietnam. In addition, migration from the lowlands to the highlands and from the Northern mountainous region to the Central Highlands has contributed to the population growth rate and put pressure on the existing forest areas. According to the General Department of Forestry, although the damaged forest area decreased by 270 ha/year, in the four years from 2016-2019, the damaged forest area was up to 7,283ha. Thus, on average, each year, Vietnam loses 2,430 ha of forest. According to the Institute of Forest Inventory and Planning, the main reason for the decrease in natural forest area is due to the conversion of use purposes, overexploitation, especially in two central coastal areas, and the Central Highlands.

The data shows that the protected forest area is declining despite the rise in the area of production forests. The reason is that people burn forests for shifting cultivation. According to the report of the Forest Protection Department, at present, the burning of forests for cultivation is becoming more and more complicated, making it difficult for the authorities to detect. As Deputy Minister of Agriculture and Rural Development, Ha Cong Tuan, states, "people usually dig at night, only a few square meters per day. After a long time, a large area of forest was burned and cleared into agricultural land. When discovered, crops were planted, a few years later, people turned forest land into cultivated land of their home" (Lao Dong Newspaper, 6/7/2020).

Secondly, illegal deforestation is a big problem in Vietnam. According to a report by the Ministry of Agriculture and Rural Development, in 2018, the competent forces detected over 12,900 violations of the forest law. According to the news report, the number of deforestation cases decreased. However, the number of cases handled and criminally prosecuted increased sharply with 363 cases, an increase of 51 cases (up 16\%) compared to 2017 , over $16,027 \mathrm{~m} 3$ of timber of all kinds were confiscated (down $7 \%$ compared to 2017). In 2018, 4,967 cases of illegal transportation and sale of timber and forest products (down 25\% compared to 2017) were discovered and processed, and 16,027 m3 of timber were confiscated. In 2019, the deforestation was discovered 1.179 cases, an increase of over $16 \%$ compared to 2018, and transportation of wildlife increased $21 \%$ (Kim Yen, "Viewpoints of deputies: What solution for deforestation", Electronic portal of the National Assembly of the Socialist Republic of Vietnam, 27/2/2020).

Due to the lack of appropriate forest management and exploitation measures, illegal logging still occurs in many localities. Due to some discrepancies in the legal system, sometimes a lack of coordination among law enforcement agencies is seen. Even sometimes illegal intimacy between forest rangers and timber loggers is found to be seen regarding the cutting down of forest trees.

Thirdly, also the forest fires, natural disasters, and risks are the primary cause of loss of forest area in Vietnam. In recent years, due to the effects of climate change, which led to erratic weather conditions, many forests area are caught in the fire. The fire severely damaged and threatened the forest vegetation, and also harshly impacted on socioeconomic and environmental development. According to the data published by the office of 
General Statistics, in the period of 10 years (2009-2018), nearly 22 thousand hectares of forests were destroyed by forest fires throughout Vietnam, which caused substantial economic damage to the country (see Fig. 2).

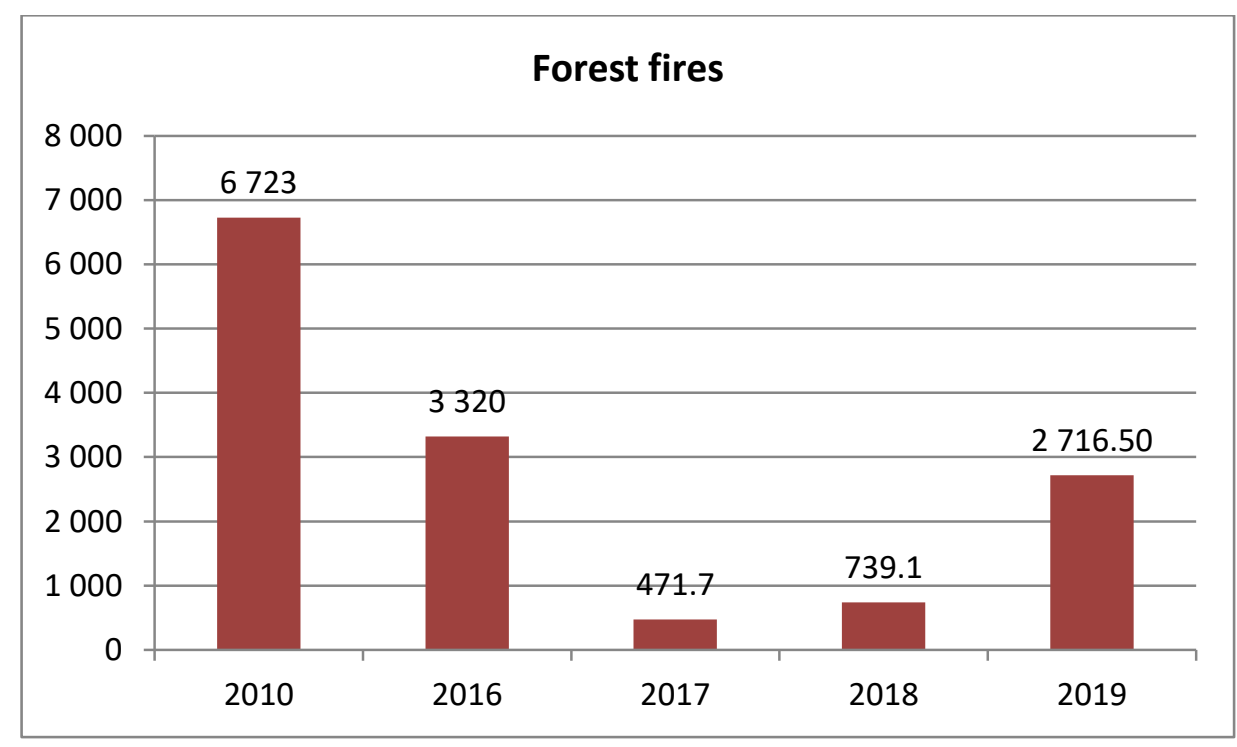

Fig. 2. The Forest fires in Vietnam (unit: hectares). Sources: General Statistics Office.

Due to a prolonged drought in the country, the highest number of forest fires occurred in 2010. The massive fires damaged nearly 6, 723 ha of forests in that year. In 2017, the sharp increase in rainfall made the weather less dry and hot, which sharply reduced the disasters at the lowest level in the past decade. The level of damage decreased to 471.7 ha, which is about 80 percent less in comparison to 2016 (3,320 ha). The Fig. reveals that the levels of damage again gradually rise in the consecutive years-2018 and 2019. In 2019, the burning of forest area was recorded to 2,716.50, which was 3.6 times higher than those of in 2018. However, the level of damage was less in comparison to those at the beginning of the decade. Particularly, in the peak months of the dry season (hot weather) in Vietnam, the majority of forests are in the state of warning of bushfire because those forests are in the risk of forest fire category $\mathrm{V}$ (hazardous level). Being listed in category $\mathrm{V}$ means the chance of catching into forest fires is very high.

\subsection{Impacts of (de)forestation on socio-economic development}

In Vietnam, forestry plays an important role in socio-economic, agricultural, and rural development. It also plays a vital role in environmental protection and national defense. According to Clause 1. Article 2 of the Law on Forestry (2017), "forestry is a technoeconomic sector, which includes forest management, protection, production, processing, and trading forest products."

In recent years, data reveals that the development of forests as well as the related forest products is gradually increasing in Vietnam. The gradual development of forestry is not playing a vital role in protecting the environment but also playing an important role in uplifting the economic sector in the country. Data published by the Vietnam Administration of Forestry shows that the growth rate of forestry production was 3.4 percent in 2011. and it gradually increased to $4.6 \%$ and $5.9 \%$ in 2012 and 2013, respectively. From 2013 up to now, the value of forestry production has increased on average by $7.29 \%$ / year, exceeding 
the set target of $4-4.5 \%$. Productivity, quality, and value of planted forests are constantly being improved. By 2017, the total area of large timber plantations in the country reached 130 thousand hectares, accounting for $3.65 \%$ of the country's planted forest area. Every year, the forestry sector contributes to greening more than 235,000 hectares of concentrated forest, of which over $90 \%$ is the production forest (Portal of Vietnam Administration of Forestry, 10/11/2018).

The wood and forest-related product processing industry has become the main exporting commodity in the group of agricultural, forestry, and aquatic products. The exportation of forestry is highly contributing to the socio-economic development of Vietnam. The forestry industries are also highly contributing to the national economy. Data shows that the export turnover of timber and non-timber forest products increased from 250 million USD in 2000 to over 6.2 billion USD in 2014. Furthermore, in 2015, it reached to 7.1 billion USD with a high proportion of trade surplus. In 2017, the forestry sector set a new record when the wood processing industry and exporting forest products earned more than 8 billion USD, three years ahead of the target set out by the Vietnam Forestry Development Strategy 2006-2020. In the list of international rankings, Vietnam sharply upgraded its ranking and became the 5th largest nation in the world, 2nd in Asia, and the first in Southeast Asia in the field of wood exportation (Portal of Vietnam Administration of Forestry, 10/11/2018).

Therefore, forestation is a crucial field in developing a green economy. Forestation not only creates jobs, helps to eliminate hunger and alleviate poverty for ethnic minorities, but also serves as a key formula to promote sustainable development in the country. Currently, however, domestic wood production only meets $20 \%$ of the total need of the raw materials for processing; still, $80 \%$ of raw materials are being imported.

In 2019, Prime Minister Nguyen Xuan Phuc, addressing the forum for "Processing and Exporting Wood and Forest Products- Success, lessons learned, breakthrough solutions," stated that the growth rate is over $800 \%$ in the past ten years is a very commendable result. Processing and exporting woods and forest products have become an essential export commodity in the country. This industry is helping the Government to deal with the growing need of the large labor market and has become high export value industries in the country. Furthermore, the Prime Minister took a long sigh and lamented, however, "the export turnover of wood and forest products in Vietnam, which accounts for only about $6 \%$ of the global market share, is still very modest." He also emphasized that the participation in the international market would open the opportunities for Vietnamese wood export in the global market in the coming days (Portal of Vietnam Administration of Forestry, 10/11/2018).

In recent years, the booming of the forest sector attracting participation and investment from all sectors-domestic as well as international. The investments are not only limited for state-owned enterprises but also open for private as well as for foreign investors. The investments are open for all fields - forestation, protection, processing, and trading forest products. According to the news report, "there were about 3.200 enterprises, including 529 foreign-invested, engaging in exporting woods and wood-related products throughout the country in 2018, which earned nearly USD 4 billion" (Nhan Dan Newspaper, 21/6/2019).

In addition, forest environmental service has become a bright spot for the socialization of the forestry sector and implementing solutions to add value from the forest. The policy of payment for forest environmental services (PFES) was one of 10 outstanding achievements of the agriculture and rural development sector in the period of 2010-15. The PFES mechanism has created a substantial change in awareness and increased effectiveness in forest protection. At the same time, that contributed to creating jobs, improving income, and improving the livelihoods of people working in the forest sector. Data shows that total PFES revenue was $8,005,179$ billion VND in the period of 2011-17. The average revenue 
increased from 1.200 to 1.300 billion VND per year in the period of 2015-16 and reached 1.709 billion VND in 2017. By October 2018, the whole country collected 2,557 billion VND from PFES, which reached $109 \%$ of the plan for 2018 and $161 \%$ over the same period in 2017. The Fund for Forest Protection and Development played a vital role in the forest restructuring process. That fund effectively mobilized the sustainable resources for forest management and protection, and also contributed to reducing the burden on the State budget invested in the forest sector.

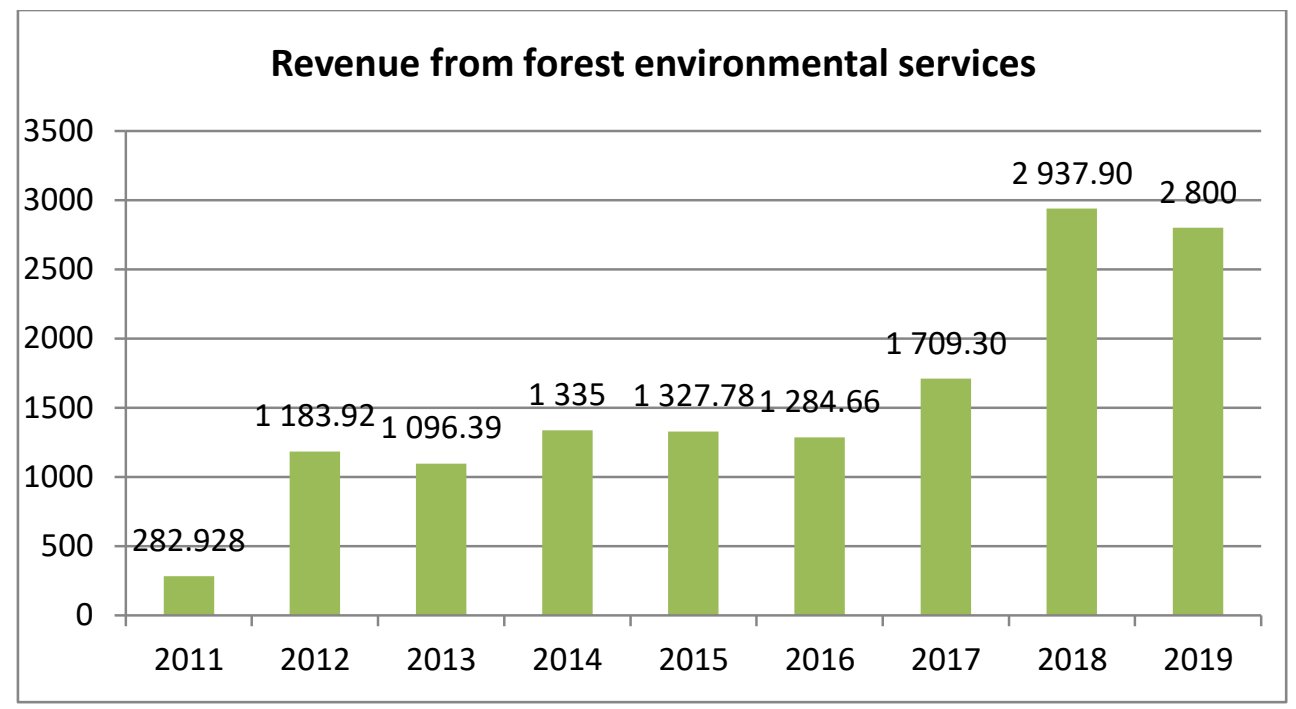

Fig. 3. Revenue from payment forest environmental services (PFES) (unit: billion VND). Sources: Ministry of Agriculture and Rural Development.

Three types of PFES have been paid since 2011. They are (1) Services of soil protection and erosion control, and sedimentation of the lake, river, and stream beds; (2) Services for regulating and maintaining water resources for production and social life; (3) Protection of natural landscapes and biodiversity conservation of forest ecosystems for tourism services.

Fig. 3 reveals that the graphs of total revenue collection through PFES are gradually increasing over the short period of its implementation, since 2011. Notably, in 2018, a total of 2,937.9 billion VND was collected throughout the country for forest environmental services, an increase of $71 \%$ compared to the total collection in 2017. Such a large amount of collection was culminated mainly due to the adjustment of electricity prices from 20 $\mathrm{VND} / \mathrm{kWh}$ of electricity to $36 \mathrm{VND} / \mathrm{kWh}$ of electricity as per the provisions of Decree No. $147 / 2016 /$ ND-CP. The Fig. shows, in 2019, however, the collection slightly slid down to 2,800 billion VND, which was spent to pay for supporting the management and protection of 6.3 million hectares of forests, accounting for $43 \%$ of the total national forest area (Nhan Dan Newspaper, 4/6/2020). The PFES money was also used for the welfare of ethnic minorities. The Government claims that the money was used to increase the household income and improve the livelihoods and social stability of more than 450,108 households of ethnic minorities. Besides, the revenue was also spent on ensuring border security and national agricultural security (Vietnam Forest Protection and Development, Ministry of Agriculture and Rural Development, 2018).

In addition, forestation develops an attractive natural landscape, which also helps to develop opportunities for ecotourism. In recent years, tourism industries have developed very rapidly in Vietnam. The development of ecotourism has become one of the top priorities for the Vietnam tourism development strategy. According to the data published in 
the news report, the average growth rate of tourists was 22 percent/year in four consecutive years (2015-19). Due to the high flow of visitors, the total revenue collected from tourism reached VND 726 trillion in 2019. The fastest-growing tourism industry made Vietnam enlisted within the ten fastest growing tourist destinations in the world (Quang Dong, "Looking back to 2019: Breakthrough year of Vietnam tourism", Nhan Dan Newspaper, 24/12/2019).

Many national parks and nature reserves are rapidly drawing tourist attractions, such as Phong Nha-Ke Bang, Cat Ba, Tam Dao, Ba Vi, Cuc Phuong, Bach Ma, and Nam Cat Tien. The ecotourism destinations are also being popular in the Mekong Delta provinces. For example, Vinh Long, Can Tho, Ben Tre, Tien Giang, and Kien Giang. Also, the Mangrove forests, like Can Gio and $\mathrm{Ca} \mathrm{Mau}$, are attractive destinations for most of the tourists. Thus, the fast-growing of ecotourism businesses are assisting in the development of biodiversity, facilitating the development of ecotourism, and ultimately contributing to the national economic development.

The main objective of the Government to grow the forestry industry is to create more jobs and income for the citizens. The Government of Vietnam is working with the aim that the forest economy must make a significant contribution in the field of socio-economic development and people's well-being. "Forestry has contributed jobs and improvement in living standard for about $25 \%$ of the Vietnamese population living in or near forests." [24, p.48] Furthermore, the communities are getting much benefit for the forest economy in most parts of the country. For example, ten years ago, the economic conditions of Bac Xa commune, Dinh Lap district, and Lang Son province were very impoverished. However, the newspaper reports that, now the whole commune has more than 11.000 ha of pine forest. On average, each household has planted from 10 to 20 ha, but some households have 40 ha too. By 2018, about 1.200 tons of pine resin was harvested. It was estimated that, on average, each pine growing household had an income of 150-200 million VND per year (Ethnic and Development Newspaper, 15/10/2019). For example, Mr. Nguyen Van Thang's family, in Tien Kien commune, Lam Thao district, Phu Tho province, received lands in a contract for forestation in 2002. The Agrinews reports that the family has earned hundreds of millions VND from the production of timber in 2 ha of Melaleuca forest (Agrinews, $11 / 12 / 2019)$.

Most notably, the forest economy has increased the household income and uplifted the livelihoods of poor people, ethnic minorities, and vulnerable groups inhabiting throughout the country. In recent years, Vietnam's economy has grown quite strongly, but still, around $10 \%$ of the population is poor and near-poor. According to the data published by the Ministry of Labor, Invalids, and Social Affairs on July 29, 2019, the current poverty rate in Vietnam is $5.23 \%$, and the near-poor household rate is $4.95 \%$. The Ministry, further, claims that forests development - protection and production - have reduced the livelihood burden for poor people in forested areas. The average annual income of households received to protect forests through the PFES policy is 1.8 million VND /household/year (Portal of Vietnam Administration of Forestry, 10/11/2018). Although this income is still low compared to living standards, it has contributed to creating jobs and improving living standards of people, especially in ethnic minority communities under forest-dependent livelihoods.

\section{Discussion}

(De)Forestation in Vietnam can be seen from a political ecology perspective, approaching through the lens of the Government as well as through citizens'.

First, from the perspective of Government, it is found that the Government has been playing a vital role in the development, protection, and production of forests in the country 
from the past. First of all, the Government has passed many relevant laws regarding the forestry sector. For example, Law on Forest Protection and Development (1991. revised in 2004 and 2016), Law on Forestry (2017), decrees on the establishment of the Forest Protection and Development Fund, payment for forest environmental services, mechanisms, and policies for forest protection and development, and policies for rapid and sustainable poverty reduction and ethnic minorities support. Strong reform policies by the Government and a large amount of capital spent for the expansion of forests, have brought Vietnam from one of the countries that used to have the lowest proportion of forest land and timber reserves per capita globally, the forest coverage rate was only $27.2 \%$ in 1995 to $41.89 \%$ in 2019 . In addition, revenue from the forestry sector has contributed to the growth of the economy, brought income and jobs to the people, and helped to enhance social stability.

Policy improvements have helped to improve forest legislation. The development of relevant laws helps the state for better management of forestry, and also creates public awareness for forest development. That is the main reason that the deforestation area decreased by $70 \%$ in the period 2011-15 compared to the period 2005-10. However, the State is still responsible for the deforestation existing in the country. As discussed above, one of the main reasons for the reduction of the area of natural forests in the country is the conversion of forest areas for the other purpose projects. According to the General Department of Forestry of Vietnam, just in five years (2012-17), the area of natural forest lost due to illegal exploitation was $11 \%$, and $89 \%$ was due to the conversion of forest area for the other sector projects. In five years, 38,300 ha of forest lands were allocated for 1.892 other sector projects. So a question arises here, who approves such projects? If the Government does not do so, then who, the central or local agencies do? Therefore, it is time for the Government to weigh the economic development goals and maintain the ecological environment. The balance between economic, social, and environmental progress only helps to attain the goals for sustainable development. In recent years, more hydroelectric projects, golf courses, and resorts are being built in Vietnam, which means the area of natural forest is shrinking. In the short term, these projects can bring some economic benefits, but in the long term, the consequences of these projects on the environment and ecosystem-change will be incurable. Such sophisticated projects only the benefit for a specific group of people, and also grow the opportunities of corruption in the country.

Despite some affirmative actions of the Government for the development of the forestry industry, there are some discrepancies too. In some regions, the Government could not attain the target of developing sustainable-forest. Also, the implementation of some national projects was very slow and ineffective. In some cases, it was found that the government agencies did not follow the regulations strictly, and also the sanctions were not enough to deter the problems. Also, some supervision mechanisms of the state were found to be lenient, which sometimes catalyzed corruption. It was also found that the roles of the local stakeholders were overlooked in the policies of the government. For example, during the supervision of the poverty reduction program in mountainous ethnic minority areas, the monitoring team of the National Assembly Standing Committee found that the ethnic minorities did not receive much benefit from the forest (Portal of the National Assembly of the Socialist Republic of Vietnam, 29/6/2019). While surveying about the reality of higher forest land occupation in the poor household area, the delegates of the monitoring team found to be surprised seeing forest land coverage. In the Ha Giang area, the monitoring team found that, on average, each household had allocated less than two hectors of forest area. From that forest, the yearly income of each household was only a few hundred thousand VND. Most notably, the monitoring team concluded that "people cannot survive from the forest" (Portal of the National Assembly of the Socialist Republic of Vietnam, 29/6/2019). It was widely perceived that the policy of payment for forest environmental 
services was a correct policy of the Government, but the allocation of funds to support forest protection contracts for the period of both 2011-15 and 2016-18 need be considered. Because in many places, the funding was not distributed, and also the level of funding allocation was different from place to place. In many cases, the effectiveness of the policy was found to be low, without any significant impact on forest protection and development. Thus, the question is how the trillions of VND earned from forest protection services were paid for?

From the perspective of citizens, people are a crucial force for developing forests and receiving benefits from forests. Since the Vietnamese Government is encouraging the participation of the private sector in forest development, protection, and production, the areas of forest under the State are gradually decreasing, and simultaneously, the areas under the management of personal and the private sector are increasing. Thus, the income of people from the forest is increasing. The income is playing a vital role in improving the livelihoods of poor households and ethnic minorities. It is also reducing the existing gap between the rich and poor, urban and rural, and delta and mountainous areas, which have become a prominent social problem in present-day Vietnam. The above results demonstrate that the engagements of citizens are remarkable for the development and protection of forests in Vietnam.

Besides those, the forestation projects are engaging many poor and unemployed citizens throughout the country. Besides illegal profit, deforestation also stems from their poverty, low pay and hard living condition. Particularly, in the upland area, the livelihood of ethnic minorities depends on the forest, but their income is not enough. Even the amount of money they receive from the payment for forest environmental services, as discussed above, is very low. According to the survey on the socio-economic status of 53 ethnic minorities conducted by the Committee for Ethnic Minorities and General Statistics Office in 2020, the poverty and near-poor household rate of households in ethnic minority areas was $35.5 \%$, which is 3.5 times higher than the national average $10.2 \%$ (Bien Phong Newspaper, 4/7/2020). Because of poverty, they have to destroy the forests for cultivation and convert forest land into agricultural land. Their prevailing poverty also instigates them for timber-logging so that they can gain additional money. Of course, such acts are illegal and should be strictly dealt with according to the law. It is also important that the state must guarantee enough participation of local stakeholders in the process of policy formulation and its implementation. Only the participation of local people makes the policies effective. It helps the forestation program closely linked with the target of socio-economic development, which ultimately brings improvements in the life of the poor.

\section{Conclusion}

The Study of (de)forestation in Vietnam from a political ecology perspective can be summarized with the following conclusions.

Firstly, policymakers need to see forests through the lens of the environment, economy, and society. The development of forests takes years, so policymakers need to consider a long-term forest development policy, even sacrifice economic benefits for ecological and social goals, ensuring sustainable development. The proposed policies also need to be closely monitored, ensuring effective implementation and amending policies if necessary.

Secondly, management levels need to monitor forestation and prevent deforestation to the maximum extent strictly. Currently, in Vietnam, the conversion of forest land for the purpose of other use is a prevalent problem, which is also a major cause for the reduction of natural forest area. It is time for the government of Vietnam to minimize the conversion of forest land into commercial project-land site and to seize opportunities for corruption and interest-groups' exploitation. The implementation of the law should be strictly followed, 
with reliable and disciplined sanctions to minimize deforestation. In addition, the State must pay attention to people's lives, ensuring that people can depend on forests for a harmonious development of the ecological, economic, and social environment.

Third, for the citizen, it is necessary to be aware of the role of forests for sustainable development of nature and social life and to be responsible for forestation. Because people are the main force for achieving the sustainable development goal of each country, including Vietnam and the forestation can play an essential role for sustainable development.

\section{References}

1. Nature Rambling, We Fight for Grass, The Science Newsletter 27, 717, Jan. 5: 14.

2. Eric R Wolf, Anthropological Quarterly, 45 (3), 201-205 (1972).

3. Piers Blaikie, The Political Economy of Soil Erosion in Developing Countries (1985).

4. M. Minch, Political Ecology. In: D.K.Chatterjee, Encyclopedia of Global Justice, Springer, Dordrecht 863-864 (2011).

5. P. Blaikie and H. Brookfield, Land Degradation and Society (1987).

6. Raymond L. Bryan, Progress in Physical Geography 22 (1), 79-94 (1998).

7. R. Peet and M.J.Watts, Economic Geography 68(3), 227-253 (1993).

8. R. Peet and M.J Watts eds, Liberation ecologies: environment, development, social movements (1996).

9. James B.Greenberg and K. Park. Thomas, Journal of Political Ecology 1, 1-12 (1994).

10. D. Rocheleau, IDS Institute for Development Studies, 26(1), 9-16 (1995).

11. Mark Q. Sutton and E.N. Anderson, Introduction to Cultural Ecology (2004).

12. Peter A. Walker, Progress in Human Geography, 29(1), 73-82 (2005).

13. Susmita Dasgupta, Uwe Deichmann, Craig Meisner, David Wheeler, World Development, 33 (4), 617-638 (2005).

14. Pamela McElwee, Journal of Sustainable Forestry, 19 (103), 97-135 (2004).

15. Philip Hirsch, Underlying causes of deforestation in the Mekong Region, 157-168 (2000).

16. Ryan Abman and Conor Carney, Land rights, agricultural productivity, and deforestation in Vietnam (2018).

17. Quy Ban Khuc, Bao Quang Tran, Patrick Meyfroidt, Mark W.Paschke, Forest Policy and Economics 90, 128-141 (2018).

18. Johan Oszwald, Jeremy Bourgoin, Valéry Gond, Lilian Blanc, Hélène Desard, Trong Van Phan, Peter Läderach, Louis Reymondin, International Journal of Applied Earth Observation and Geoinformation, 84, 101958 (2020).

19. Raymond L. Bryant and Sinead Bailey, Third World Political Ecology, 27-28 (Routledge, 1997).

20. FAO, Forest Resources Assessment Working Paper - Terms and Definitions, 3 (2015).

21. Global Forest Watch, Tree cover lost in Vietnam, (2019).

22. Voices of Mekong Forest (V4MF), Assessing Forest Governance in Vietnam Identifying key challenges and interventions to strengthen governance, 2 (2018).

23. Luong Thi Hoan, Journal of Vietnamese Environment, 6 (2), 171-177 (2014).

24. Forest Science Institute of Vietnam (FSIV), Vietnam forestry outlook study, 48 (2009). 
25. Department of Forestry Production Development, Sustainable forest management, and forest certification in Vietnam: From policy to practice, Hanoi (2018).

26. CIEM, DOE, United Nations University, UNU-WIDER, Implications of Climate Change for Economic Growth and Development in Viet Nam, 1 (Statistical Publisher, Hanoi, 2012). 